\title{
Contribution of Information and Communication Technologies to Growth
}

Christine Zhen-Wei Qiang

Alexander Pitt

with Seth Ayers 


\section{Contribution of Information and Communication Technologies to Growth}

Christine Zhen-Wei Qiang

Alexander Pitt

with Seth Ayers 
Copyright (C) 2004

The International Bank for Reconstruction and Development / The World Bank

1818 H Street, N.W.

Washington, D.C. 20433, U.S.A.

All rights reserved

Manufactured in the United States of America

First printing: December 2003

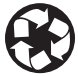

printed on recycled paper

\section{3}

World Bank Working Papers are published to communicate the results of the Bank's work to the development community with the least possible delay. The typescript of this paper therefore has not been prepared in accordance with the procedures appropriate to journal printed texts, and the World Bank accepts no responsibility for errors. Some sources cited in this paper may be informal documents that are not readily available.

The findings, interpretations, and conclusions expressed in this paper are entirely those of the author(s) and do not necessarily reflect the views of the Board of Executive Directors of the World Bank or the governments they represent. The World Bank cannot guarantee the accuracy of the data included in this work. The boundaries, colors, denominations, and other information shown on any map in this work do not imply on the part of the World Bank any judgment of the legal status of any territory or the endorsement or acceptance of such boundaries.

The material in this publication is copyrighted. The World Bank encourages dissemination of its work and normally will grant permission for use.

Permission to photocopy items for internal or personal use, for the internal or personal use of specific clients, or for educational classroom use, is granted by the World Bank, provided that the appropriate fee is paid. Please contact the Copyright Clearance Center before photocopying items.

Copyright Clearance Center, Inc.

222 Rosewood Drive

Danvers, MA 01923, U.S.A.

Tel: 978-750-8400 • Fax: 978-750-4470.

For permission to reprint individual articles or chapters, please fax your request with complete information to the Republication Department, Copyright Clearance Center, fax 978-750-4470.

All other queries on rights and licenses should be addressed to the World Bank at the address above, or faxed to 202-522-2422.

ISBN: 0-8213-5722-0

eISBN: 0-8213-5723-9

ISSN: $1726-5878$

Christine Zhen-Wei Qiang is Economist in the Global ICT Department at World Bank. Alexander Pitt is Economist in the Policy Development and Review Department at the International Monetary Fund. Seth Ayers is Consultant to the Global ICT Department at World Bank.

\section{Library of Congress Cataloging-in-Publication Data has been requested.}




\section{CONTENTS}

Abstract v v

Acknowledgments vii

Abbreviations and Acronyms ix

1. Introduction 1

2. Assessing the Contribution $\quad 3$

3. The Contribution of ICT to Economic Growth $\quad 7$

4. Factors Influencing the Contribution of ICT to Economic Growth 15

5. Policy Implications $\quad 19$

$\begin{array}{lr}\text { 6. Conclusions } & 23\end{array}$

$\begin{array}{lr}\text { References } & 25\end{array}$

\section{BOXES}

$\begin{array}{ll}\text { 1. Disparity in R\&D Spending } & 18\end{array}$

\section{Figures}

1. Channels of Contribution to Economic Growth by ICT 4

2. Global Spending on ICT Goods $\quad 5$

3. Contribution of ICT to Labor Productivity Growth (Percentage of GDP) 9

4. Cellular Phone Explosion in Sub-Saharan Africa 13

5. Ten Countries with the Highest Growth Rate of ICT Spending, 1993-2001 16

6. Cumulative Annual Growth Rate of Mainline and Mobile Penetration in Developing countries, 1996-2001

\section{TABLES}

1. Contribution of ICT Capital Deepening and Growth of TFP in ICT Sectors in Selected Countries (1995-2000)

2. Change in Growth Contribution of ICT, 1996-1999 versus 1991-1995 10

3. The Widening Digital Divide in Asia 10

4. Relative Price Change and Social Savings in Selected Countries 12

5. Information and Communication Infrastructure, 1995-2001 17 

$\mathrm{T}$

he worldwide development of information and communication technology (ICT) has accelerated dramatically over the past decade. Increased ICT production and use has the potential to influence economic growth positively. This paper focuses on the linkage between ICT and output growth and summarizes the findings in the literature on the contribution of ICT to economic growth arising from capital deepening and increases in total factor productivity. It looks at the methodologies used to assess the magnitude of the different channels through which ICT influences productivity growth, summarizes the key factors that increase and obstruct ICT expansion, and outlines the challenges developing countries face in maximizing ICT's contribution to growth. Strengthening institutions to create an environment that attracts ICT investment and promotes ICT use; exploiting network and spillover effects by creating domestic demand; and promoting "adaptation close to use" to match local capacity and local needs have been identified as policies to surmount these challenges. 



\section{ACKNOWLEDgMeNTS}

$\mathrm{T}$ his paper draws upon research under the World Bank Infrastructure Network research project "Contribution of ICT to Growth." The views expressed are those of the authors and do not necessarily reflect those of the World Bank, its executive directors or the countries they represent.

The team of this paper consists of Christine Zhen-Wei Qiang (Task Manager, cqiang@worldbank.org), Economist, Global ICT Department (GICT); Alexander Pitt, Economist, Policy Development and Review Department, IMF; and Seth Ayers, Consultant, GICT. The editorial assistance provided by Alicia C. Shepard and Andrea Ruiz-Esparza, and research assistance by Jian Chang during the early stage, are hereby acknowledged.

Valuable contributions and comments were received from our reviewers Peter McCawley (President, ADB Institute), John Daly and other World Bank Group colleagues including Laurent Besançon, Rachele Gianfranchi-Hirschhofer, Carlos Gomez, Jennifer Gui, Pierre Guislain, Charles Kenny, Bruno Lanvin, Gareth Locksley, Tenzin Dolma Norbhu, Shilpa Pradhan, Carlo Rossotto, David Satola, Robert Schware, Alexandre Serot, Robert Stephens, Jiro Tominaga, and Howard Williams.

We are also grateful for the outside contributions and comments received from Benoit d'Ansembourg (Advisor for the Development Gateway), Daniel Chudnovsky (Director of the Centro de Investigaciones para la Transformación), Francesco Daveri (Professor of Economic Policy at the Università di Parma), Cornelio Hopmann (Nicaragua Country Gateway Coordinator), Kenneth Kraemer (Professor of Information Systems at the University of California, Irvine), Andres Lopez (Associate Professor of Development Economics at the University of Buenos Aires), Alfonso Molina (Professor of Technology Strategy at the University of Edinburgh), Dirk Pilat (Directorate for Science, Technology and Industry at the OECD), Matti Pohjola (Professor of Economics at the Helsinki School of Economics), Michael Ryan (Visiting Associate Professor of International Political Economy at Georgetown University), and Poh Kam Wong (Associate Professor of Business Policy at the National University of Singapore). 



\section{Abbreviations ANd ACRONYmS}

NIEs Newly industrialized economies

FDI Foreign direct investment

GDP Gross domestic product

GNP Gross national product

ICT Information and communication technologies

IT Information technology

ITU International Telecommunications Union

OECD Organization for Economic Cooperation and Development

R\&D Research and development

TFP Total factor productivity

WTO World Trade Organization 

Chapter I

INTRODUCTION

$\mathrm{T}$

The worldwide development of information and communication technology (ICT) ${ }^{1}$ has accelerated dramatically over the past decade, spurred by an increasingly global economy. Technological advances and increased competition have led to falling prices for ICT goods and services, and that has provided a strong incentive to replace other forms of capital and labor with information technology equipment (Jorgenson 2001). The revolution in ICT sectors coupled with a loosening of trade restrictions has encouraged the growth and expansion of ICT. Consequently, investment in ICTs has grown substantially in both developed and developing countries. In fact, expenditures rose twice as fast in developing countries from 1993 to 2001 compared to the OECD average. ${ }^{2}$

Increased ICT production and use has contributed significantly to economic growth. Based on the increase in ICT investment in industrial countries between 1995 to 2000, Haacker and

1. ICT, as defined in the Information \& Communication Technology Sector Strategy Paper of the World Bank Group (April 2002, http://info.worldbank.org/ict/ICT ssp.html), consists of hardware, software, networks, and media for collection, storage, processing, transmission, and presentation of information (voice, data, text, images).

ICT-producing sectors are defined by OECD as a combination of manufacturing and services industries that capture, transmit and display data and information electronically. Manufacturing includes office, accounting and computing machinery; insulated wire and cable; electronic valves and tubes and other electronic components; television and radio transmitters and apparatus for line telephony and line telegraphy; television and radio receivers, sound or video recording or reproducing apparatus and associated goods; instruments and appliances for measuring, checking, testing, navigating and other purposes, except industrial process equipment; and industrial process equipment.

Services include wholesaling of computers, computer peripheral equipment and software; wholesale of electronic and telecommunication parts and equipment; renting of office machinery and equipment (including computers); telecommunications; computer and related activities (OECD 2002a).

ICT-using sectors are defined in this paper as sectors that use ICT products in their business.

2. The cumulative annual growth rate of ICT expenditures in developing countries was 12 percent during this period and 6 percent in developed countries. 
Morsink (2002) estimate an average increase in growth of total factor productivity (TFP) of about one-third of a percentage point per year. However, there are significant variations. In the United States, which experienced a higher-than-average increase in ICT expenditures during this period, the increase in TFP growth is projected at about one-half of a percentage point per year. Though the United States is the most striking example, other countries are enjoying the benefits of ICT capital investment on economic growth. The evidence suggests that ICT production and diffusion can generate significant returns in both industrial and developing countries. For example,

Malaysia's return on ICT capital (44.8 percent) is about three times higher than that for non-ICT capital (15.4 percent), point out Lee and Khatri (2003).

The increased production of ICTs contributes to output, employment, ${ }^{3}$ and export earnings, while ICT use increases productivity, competitiveness, and growth. ICT has the potential to make governments more efficient, more inclined to share information, more transparent and accountable (Joseph 2002). ${ }^{4}$ Governments can also use ICT to connect isolated rural communities with urban centers as well as offer the poor economic opportunities.

The focus of this paper is the impact of ICT on economic growth due to capital deepening and increases in total factor productivity (TFP). ${ }^{5}$ Chapter 2 outlines the methodologies used to evaluate the different ways ICT influences productivity growth. Chapter 3 illustrates the magnitude of ICT's contribution to growth in various countries and the distribution of benefits that follows between and within countries. Chapter 4 summarizes the key factors that increase and obstruct ICT expansion, and defines the challenges developing countries face in maximizing ICT's contribution to growth. Chapter 5 concludes with policy implications for developing countries.

3. In 2000, the White House estimated that more than 13 million Americans held ICT-related jobs and the rate of growth in this sector was six-times as fast as overall job growth (World Bank 2002). In the same year, India's software industry alone employed 400,000 people and produced $\$ 8$ billion in sales (Economist 11/10/01).

4. An example is GovernmentNet, Brazil's government portal, which provides more than 4,800 types of information and 800 services, including income tax declaration, registration of government suppliers, primary and secondary school enrolment and information on social security benefits (http://www.redegoverno.gov.br). Singapore estimates that the use of ICT by government services has yielded a return of $\$ 2.70$ for each dollar invested (Based on UNESCAP 1999 and Chapter 3 referenced by World Bank (2002)).

5. Output growth stemming from an expansion of the labor force is not discussed in this paper. 
Chapter 2

\section{Assessing the Contribution}

\section{Research Methodologies in the Literature}

Researchers employ a variety of methodologies to assess the contribution of ICT to economic growth. The most common are (i) growth accounting, (ii) sectoral contribution analysis to productivity growth within an economy, and (iii) cross-country regression analysis.

\section{Growth Accounting}

Growth accounting measures increase in factors of production, that is, stocks of physical capital, human capital and "raw" labor. Physical capital is defined as the number of non-human assets (such as factories or roads) measured by their constant dollar value. Human capital is usually measured by the average years of schooling, and "raw" labor is the number of people of working age. Increases in physical and human capital and labor will yield an expected increase in productivity. TFP growth is then defined as the actual output growth minus the growth rates of capital and labor stocks, weighted by their contribution to output. It represents a measure of the efficiency with which capital and labor are combined to produce output.

\section{Analysis of Sectoral Contribution}

Sectoral contribution analysis focuses on the primary sectors that produce and use ICT. This type of analysis explores the contributions of individual economic sectors to economic growth. In this analysis, employment levels, capital allocation, and overall contribution to gross domestic product (GDP) are taken into account. This type of analysis helps explain why some important ICT-producers, like Japan, experience much slower economic growth from ICT use compared to some insignificant ICT-producers, like Australia. It also explores the extent a domestic ICT-producing sector facilitates the spread ICT within a country and/or among its neighbors.

\section{Regression Analysis}

Regression analysis is used to determine the interdependency of ICT variables on economic growth. Correlation of ICT-related factors-such as expenditure on ICT and level of education- 
with growth of TFP offers insights into the variables that determine growth and those that do not. For example, Haacker and Morsink (2002) use cross-section and panel regressions to understand variation in growth of TFP and ICT-related activities in different countries. Once the key variables are identified, government leaders can take them into account to make pro-growth policy decisions.

\section{Channels of ICT's Contribution to Economic Growth}

There are three channels through which ICT can influence economic growth (see Figure 1):

1. TFP growth in sectors producing ICT

2. Capital deepening

3. TFP growth through reorganization and ICT usage.

The ICT revolution partly consists of high TFP growth in industries producing ICT, driven by rapid technological progress. The main characteristic of this revolution is the rapidly increasing computing power of new ICT products. In particular, memory chips, which as long as "Moore's Law" holds, double their computing power every 18 months. Such performance increases are equivalent to rapid TFP growth in ICT-producing sectors, which in turn raise the average TFP growth of the economy. ${ }^{6}$

The second channel where ICT can influence productivity is when higher levels of financial investment in ICT bring about new products and falling prices (Figure 2). This may lead to an increase in the real capital stock per worker-that is, ICT-related capital deepening across the economy (implying a lowering of the marginal cost of capital). To the extent that ICT is a sub-

\section{Figure I: ChanNels of CONTRIBUtion to Growth by ICT}

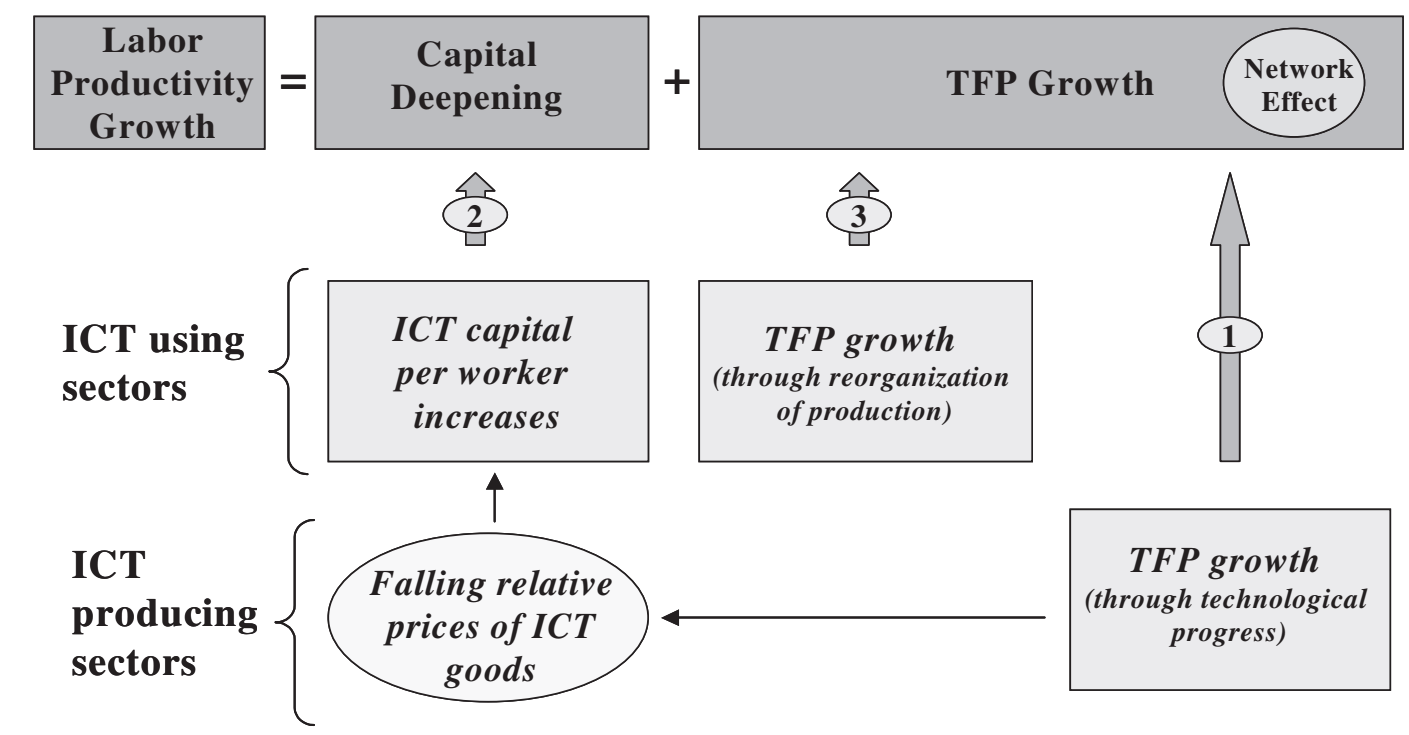

6. It is important to note that only the difference in the growth of TFP between ICT-producing sectors and non-ICT producing sectors would be attributed to ICT. If the ICT sector did not exist (and therefore all ICT products would be imported), the production factors used in this sector would otherwise be used elsewhere, and be subject to the rate of productivity growth for non-ICT producing sectors. 


\section{Figure 2: GLOBAL SPENDING ON ICT GOODS ${ }^{7}$}

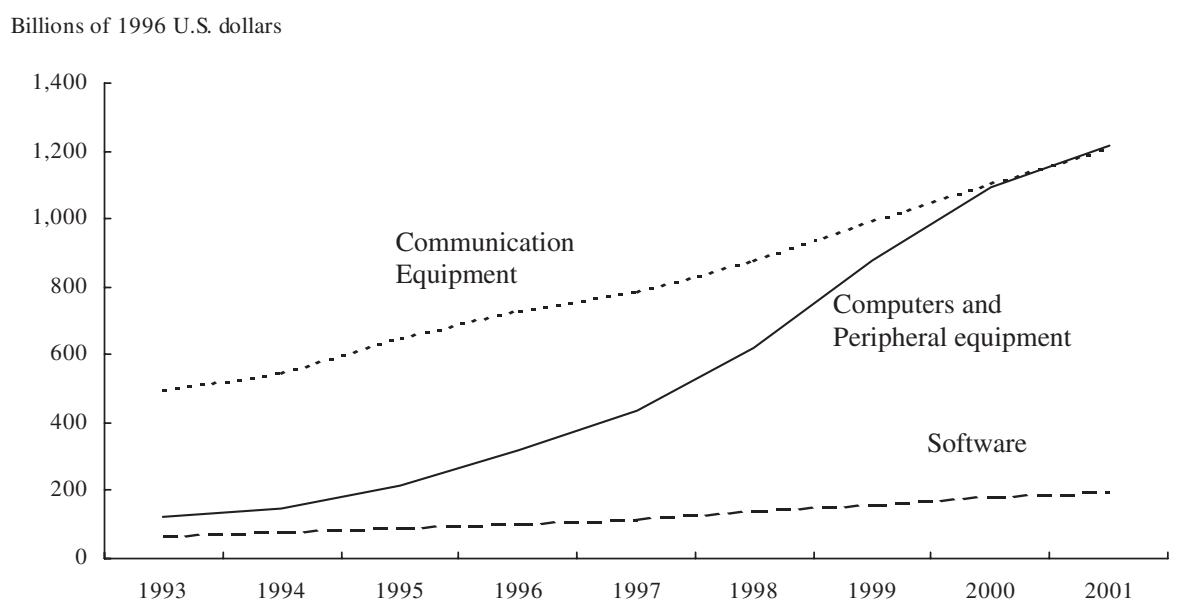

Source: WITSA for ICT spending data; US Bureau of Economic Analysis (BEA) for investment price deflators of computers and peripheral equipment, communication equipment, and software.

stitute for other forms of capital (and labor), it frees productive resources to expand the overall output of the economy; to the extent that it is a complement, it raises the productivity of the existing capital stock and of labor.

The third channel is more difficult to characterize, yet it may have the most profound long-term effects. Advances in ICT have the potential to significantly reorganize how goods and services are created and distributed. ICT applications can create new markets, new products ${ }^{8}$ and new ways of organizing how society operates - in much the same way the electric motor, the telephone and the computer chip have done previously. One must look at how these technological advancements affect the entire economy rather than just focus on the benefits of improving technology in one ICT-producing sector. Such dramatic technological changes across the entire economy ${ }^{9}$ naturally affect TFP growth and demonstrate ICT's potential to stimulate productivity. Much has been written about the multitude of ways ICT can reduce administrative procedures, disseminate information cheaply and efficiently, and trigger new business models that are more productive than existing models. While these predictions may be exaggerated, sectors such as retail, financial services, and transportation are benefiting from ICT utilization. ${ }^{10}$

7. This figures shows real growth of spending on ICT, using BEA hedonic unit prices that capture both price and quality changes.

8. There is the so-called "incorporation of ICT in products", i.e. ICT is embedded in products and improves their quality and performance. One example is cars that have better performance with internal computers and electronics.

9. In fact, in the late 1990s, the concept of "new economy" has been used widely to mark the association of non-inflationary growth with high investment in ICT and a restructuring of the economy. Characteristics of the "new economy" include higher TFP growth due to more efficient business practices linked to the use of ICT; and increasing returns to scale, network effects and externalities from the use of ICT in parts of the economy (OECD 2000).

10. For instance, a recent study on the transport industry in Poland showed that the market share of transport companies using sophisticated software increased from 45 percent in 2000 to 60 percent in 2001 (Piatkowski 2002). 

Chapter 3

\section{The Contribution of ICT TO ECONOMIC GROWTH}

\section{Magnitude of the Three Channels}

The existing literature has established that ICT is contributing to labor productivity through both increases in the levels of ICT capital, and TFP growth in sectors producing ICT (see Table 1). The precise magnitudes of these contributions, however, remain a subject of debate. Results based on the standard growth accounting decomposition show that the contributions to economic growth through these two channels increased during the 1990s in developed countries and in East Asia's emerging markets (see Figure 3 ).

However, no consensus exists on ICT's effect on generalized TFP ${ }^{11}$ growth through growth accounting exercises and using the sectoral approach. Evidence from cross-country regression analysis that examines the relationship between TFP growth and ICT production and use is equally ambiguous, with estimated coefficients and standard errors being sensitive to specification, time period, and set of countries included in the regression (IMF 2001).

\section{Cross-Country Evidence}

Various results reached by different countries and regions fuel the debate over exactly how much influence ICT has on economic growth.

The US, for example, has enjoyed markedly better results from investment in ICT than most other countries. Jorgenson (2001) found capital inputs to primarily drive US economic growth during the post-WWII period. Since 1995, capital inputs have raised output growth by nearly a full percentage point-ICT accounts for more than half of that increase (Jorgenson 2001). Computers are largely responsible for this increased growth. But communications equipment and software have also contributed significantly. In contrast to the contribution of ICT capital deepening to

11. The debate focuses on whether the remainder of the acceleration reflects cyclical factors or structural acceleration. It may be partially due to possible lags between ICT adoption and economy-wide productivity growth. 


\begin{tabular}{|c|c|c|c|c|}
\hline & $\begin{array}{c}\text { ICT-Related } \\
\text { Capital } \\
\text { Deepening }\end{array}$ & $\begin{array}{c}\text { Contribution of } \\
\text { ICT Production } \\
\text { to TFP }\end{array}$ & $\begin{array}{l}\text { Total TFP } \\
\text { Growth }\end{array}$ & $\begin{array}{c}\text { Total Labor } \\
\text { Productivity } \\
\text { Growth }\end{array}$ \\
\hline \multicolumn{5}{|l|}{ Developed Countries I/ } \\
\hline Austria & 0.37 & 0.10 & 1.63 & 3.06 \\
\hline Denmark & 0.41 & 0.06 & 0.72 & 1.84 \\
\hline Finland & 0.33 & 0.17 & 3.18 & 3.29 \\
\hline France & 0.32 & 0.22 & 0.70 & 1.35 \\
\hline Germany & 0.37 & 0.16 & 0.91 & 1.76 \\
\hline Ireland & 0.68 & 3.02 & 4.27 & 5.88 \\
\hline Italy & 0.38 & 0.15 & 0.25 & 1.13 \\
\hline Netherlands & 0.55 & 0.10 & 0.21 & $0.4 I$ \\
\hline Portugal & 0.30 & 0.03 & 0.92 & 2.49 \\
\hline Spain & 0.17 & 0.12 & -0.14 & 0.22 \\
\hline Sweden & 0.50 & 0.09 & 0.96 & 1.96 \\
\hline UK & 0.65 & 0.32 & 0.49 & 1.76 \\
\hline USA & 0.75 & 0.43 & 1.21 & 2.21 \\
\hline \multicolumn{5}{|l|}{ Developing Countries 2/ } \\
\hline China & 0.27 & $\mathrm{n} / \mathrm{a}$ & 3.76 & 7.41 \\
\hline Hong Kong, SAR & 1.17 & 0.41 & -2.36 & -0.49 \\
\hline India & 0.11 & 0.05 & 2.15 & 5.82 \\
\hline Indonesia & 0.19 & 0.63 & -4.30 & -0.69 \\
\hline Malaysia & 0.57 & 3.47 & -1.12 & 1.78 \\
\hline Philippines & 0.31 & 0.65 & 1.11 & 2.12 \\
\hline Singapore & 1.36 & 7.04 & -0.28 & 2.68 \\
\hline South Korea & 1.10 & 0.66 & 3.00 & 5.21 \\
\hline Taiwan, Province of China & 0.58 & 1.90 & 2.29 & 5.04 \\
\hline Thailand & 0.23 & 1.90 & -0.83 & 1.21 \\
\hline
\end{tabular}

I/ 1995-2000 data.

2/ 1995-1999 data.

Source: Based on findings from Van Ark et al. (2003) and Lee and Khatri (2003).

economic growth in the US, evidence supporting TFP growth due to ICT is more opaque, particularly for ICT utilization, the third channel. The evidence suggests that production of ICT increases total US growth of TFP by about one-quarter of a percentage point per year. ${ }^{12}$ Oliner and Sichel (2000) estimate that the combined TFP effect from ICT utilization and computer production accounts for about two-thirds of the one percentage point increase in productivity growth in the United States between the first and second halves of the 1990s.

In Europe, ICT's contribution to growth has been more sporadic. Daveri (2002 and 2003) concludes that between 1995 and 2000, growth contributions from ICT capital rose in 10 out of 14 EU countries. In only six of the 14 countries, however, was an increase of ICT-related capital deepening associated with higher aggregate TFP or growth in labor productivity (see Table 2). For instance, despite ICT expenditures nearly comparable to the United States, the United Kingdom

12. The average calculated from Van Ark et al. (2003), Gordon (2003), US CEA (2001), Jorgenson and Stiroh (2000), Oliner and Sichel (2000), and Lee and Khatri (2003) is 0.28 percentage point. 


\section{Figure 3: CONTRIBUtion OF ICT TO LABOR Productivity GROWTH $(\% \text { of GDP })^{13}$}

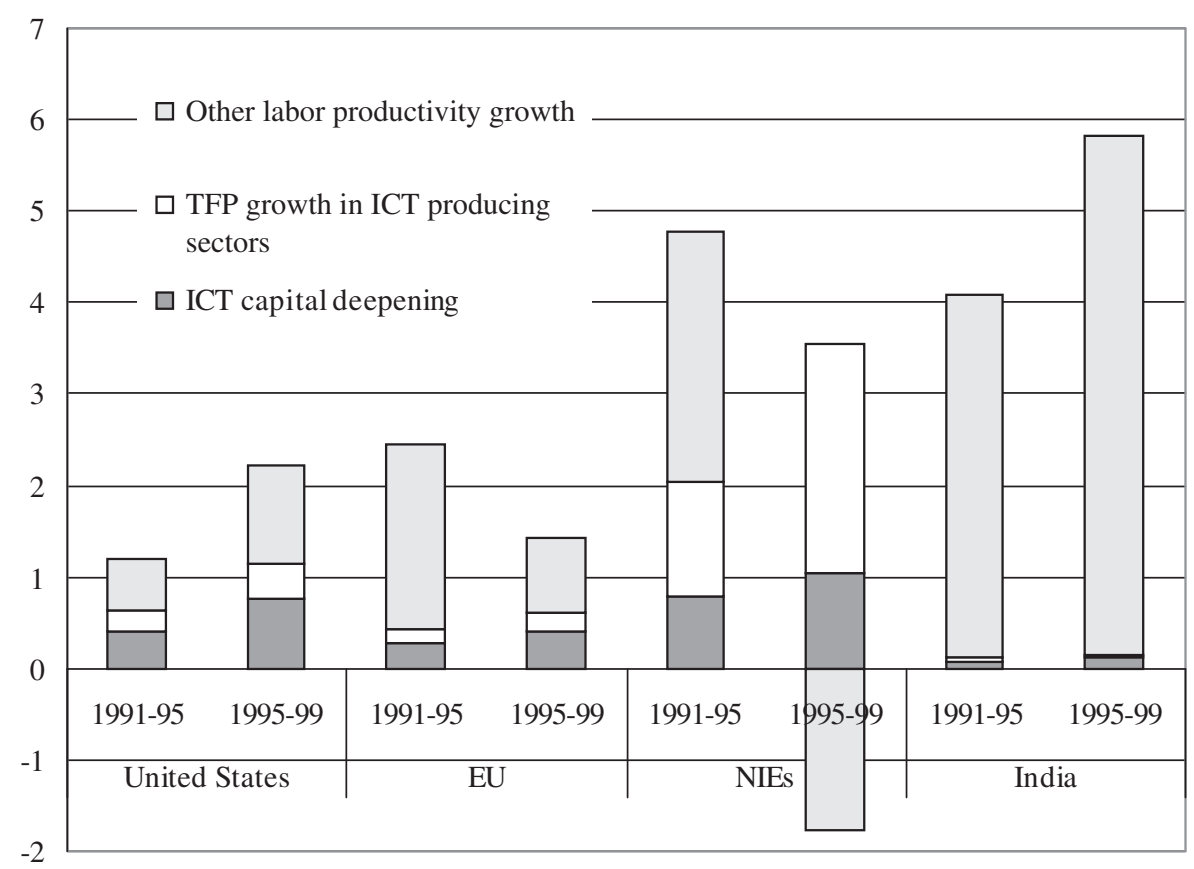

Source: Based on findings from Van Ark et al. (2003) and Lee and Khatri (2003).

has not achieved similar TFP growth. One possible explanation is that TFP growth attributed to increased ICT capital deepening is offset by TFP decreases in other sectors. Unlike other EU members, Belgium, Germany, Netherlands, and Spain have experienced stagnating or mildly declining growth in contributions from ICT capital, on top of declining TFP growth during the same period.

In East Asia, the ICT sector is growing in importance, particularly in production. Today, 28 percent of the region's manufacturing exports are ICT goods (Kenny 2003). ICT production has contributed significantly to GDP growth in the region. In Japan, the contribution of ICT-related capital deepening to growth increased by about one-half to three-quarters of a percentage point between the early and late 1990s. ${ }^{14}$ However, high levels of ICT production have not resulted in increased use of the technology. Wong (2001) observes that while the Asia region has captured a disproportionately high share of global ICT production, it trails other regions in ICT adoption. ${ }^{15}$ Furthermore, within the region, the divide is expanding between more advanced countries such as Japan and the Asian NIEs and other developing Asian countries (see Table 3). The region's fragmentation into a large number of relatively small markets, divided by language, culture, technical standards, weak legal institutions, and mistrust for e-commerce transactions inhibits regional diffusion of ICT and internet-based applications.

13. The data are simple averages of some EU countries (Austria, Denmark, Finland, France, Germany, Italy, Netherlands, Portugal, Spain, Sweden and UK) and of Asian newly Industrialized Economies (NIEs: Hong Kong SAR, Korea, Singapore and Taiwan Province of China).

14. Study by Japan Economic Planning Agency (2000).

15. Controlling for the economic status of Asian countries, as measured by GDP per capita, Wong found that the region had lower than expected ICT adoption levels. 


\begin{tabular}{|c|c|c|}
\hline Country & $\begin{array}{l}\text { Change in Growth Contribution of } \\
\text { ICT Capital Deepening }\end{array}$ & $\begin{array}{l}\text { Change in Aggregate } \\
\text { TFP Growth }\end{array}$ \\
\hline Austria & 0.04 & 2.46 \\
\hline Belgium & -0.07 & -0.49 \\
\hline Denmark & 0.14 & -2.37 \\
\hline Finland & 0.32 & 1.13 \\
\hline France $2 /$ & 0.08 & 0.41 \\
\hline Greece & 0.21 & 1.86 \\
\hline Germany I/, 2/ & 0.00 & -0.59 \\
\hline Ireland & 0.35 & 0.46 \\
\hline Italy 2/ & 0.06 & -1.50 \\
\hline Netherlands & -0.08 & -0.94 \\
\hline Portugal & 0.07 & I.II \\
\hline Spain & -0.18 & -0.90 \\
\hline Sweden & 0.33 & $-0.4 I$ \\
\hline UK 2/ & 0.25 & -1.04 \\
\hline
\end{tabular}

I/ 1992-1995.

2/ 1995-2000.

Source: Daveri (2002 and 2003)

\section{TAble 3: The Widening Digital Divide IN Asia} (Per I,000 inhabitants)

\begin{tabular}{|c|c|c|c|c|}
\hline & \multicolumn{2}{|c|}{ Fixed+Cellular Phones } & \multicolumn{2}{|c|}{ Personal Computers } \\
\hline & 1995 & 2001 & 1995 & 2001 \\
\hline Asia NIEs + Japan I/ & 547 & 1,207 & 118 & 385 \\
\hline Other Asia 2/ & 37 & 130 & 8 & 21 \\
\hline \multirow[t]{3}{*}{ Other Asia in percent of Asian NIEs + Japan } & $6.8 \%$ & $10.8 \%$ & $6.8 \%$ & $5.5 \%$ \\
\hline & \multicolumn{2}{|c|}{ Internet Hosts } & \multicolumn{2}{|c|}{ ICT Per Capita 3/ } \\
\hline & 1995 & 2001 & 1995 & 2001 \\
\hline Asia NIEs + Japan I/ & 2 & 48 & 6,482 & 8,955 \\
\hline Other Asia 2/ & 0.03 & 0.49 & 363 & 448 \\
\hline Other Asia in percent of Asian NIEs + Japan & $1.5 \%$ & $1.0 \%$ & $5.6 \%$ & $5.0 \%$ \\
\hline
\end{tabular}

I/ Asian NIEs are Hong Kong, South Korea, Singapore and Taiwan.

2/ Other Asia is Indonesia, Malaysia, Philippines, Thailand, and Vietnam.

$3 /$ In US dollars per inhabitant.

Source: WITSA for ICT per Capita and ITU for all other. 
In some regions, there are few cross-country findings on ICT's contribution to economic growth. In regions such as South Asia, ${ }^{16}$ the Middle East, and Africa there is no data available for growth accounting analysis. In Latin America and in Central and Eastern Europe, ${ }^{17}$ ICT investment levels are too small to measure their impact on economic growth, according to Piatkowski (2002). This is an area for future study.

\section{Distribution of the Benefits}

While data shows that ICT's contribution has varied across regions, it is also useful to examine the impact of ICT on specific groups within the ICT production and utilization chain. In principle, the benefits of a technology could accrue to owners (in the form of higher profits), users (through lower prices), or labor (through higher wages) (IMF 2001). Other benefits occur between innovators and adapters or-within countries-between groups of people.

\section{Who actually benefits most from the ICT revolution?}

\section{ICT Producers vs. ICT Consumers}

The exceptional economic success of some major ICT producers, including East Asia and Ireland, during the last decade has generated interest in ICT production as a potential vehicle for greater prosperity and economic development. These countries have apparently benefited from continuous technological improvement.

The plummeting prices of ICT goods - that is, deteriorating terms of trade for producers - in recent years, however, have led some to conclude that welfare gains are primarily reaped by users of ICT. ${ }^{18}$ Bayoumi and Haaker (2001) claim that the ICT industry is subject to perfect competition and therefore, no excess profits can be made that would generate significant economic benefits for producers. ${ }^{19}$ As a result, they conclude that welfare gains are significantly higher for the consumer countries than for those that produce ICT (see Table 4).

Countries that produce ICT may face another challenge created by policies that over-emphasize ICT production. East Asia is a good example. Through targeted governmental policies East Asia successfully produces and exports ICT. But as previously noted, the region lags behind in ICT use. The region's preoccupation with promoting ICT production has resulted in a minimal allocation of resources to promote its use-the assumption appears to have been that ICT production would automatically lead to widespread use of it, but it has not. India, for example, is a large exporter of software-related goods and services, but its over-emphasis on IT production has not led to a large-scale increase in domestic ICT use. Also, India's focus over the last decade on an export-led development strategy that capitalized on its comparative advantage in the software sector has crowded out, at least in the short-run, other industries competing for highly-skilled labor and capital resources (Joseph 2002). As a result, India's net export earnings from ICT were less impressive than gross earnings suggest because other industries failed to develop at the same rate as ICT.

16. India is an exception due to its successful software export industry.

17. ICT and R\&D expenditure levels are quite low in the transition economies of Central and Eastern Europe. Consequently, ICT expansion has been minimal thus far, but the impending membership of several of these countries to the European Union coupled with increasing FDI flows are positioning the more affluent transition economies for greater ICT diffusion in the near future (Piatkowski 2002).

18. On the production side, technological improvements incorporated in the drop in relative prices of IT goods raise productivity growth, most notably in Singapore and Malaysia. However, because most of these goods are exported to the rest of the world, and hence exchanged for non-ICT goods, which are becoming relatively more expensive, the benefits to real domestic demand are significantly smaller. Conversely, countries that import ICT goods from abroad gain from falling prices and continuing improvements in trade terms (IMF 2001).

19. This is not to deny that in some ICT markets, notably where strong externalities exist, competition is imperfect, and individual companies can obtain a monopolistic market position. 


\begin{tabular}{|c|c|c|c|}
\hline & $\begin{array}{l}\text { Relative Price of } \\
\text { ICT Goods } \\
\end{array}$ & Social Savings & ICT Production \\
\hline & $\begin{array}{c}\text { Percentage } \\
\text { Change }\end{array}$ & $\begin{array}{c}\text { Change in Percentage } \\
\text { Points of GDP }\end{array}$ & $\begin{array}{c}\text { Average Share of } \\
\text { GDP }\end{array}$ \\
\hline & 1992-1999 & $1992-200 \mid$ & $1996-2000$ \\
\hline \multicolumn{4}{|l|}{ Producers } \\
\hline Ireland & -55 & 2.7 & 11.5 \\
\hline Malaysia & -46 & 2.5 & 21.3 \\
\hline Singapore & -54 & 4.0 & 34.4 \\
\hline Taiwan & -47 & 1.9 & 7.4 \\
\hline Thailand & -50 & 1.4 & 6.2 \\
\hline Average & & 2.5 & 16.2 \\
\hline \multicolumn{4}{|l|}{ Consumers } \\
\hline Australia & -49 & 3.6 & 0.2 \\
\hline Switzerland & -50 & 3.1 & 0.5 \\
\hline United Kingdom & -55 & 3.5 & 1.8 \\
\hline United States & -58 & 4.1 & 1.7 \\
\hline Average & & 3.6 & 1.7 \\
\hline
\end{tabular}

Source: Bayoumi and Haaker (200I).

In such countries, governments should develop a more balanced economic growth strategy that takes into account the complementary role of the domestic market for ICT. This could lead to greater innovation and economic growth.

\section{ICT Innovators vs. ICT Adaptors: Late-comer Advantages and Disadvantages}

Although developing countries currently lag behind developed countries in adopting ICT, low opportunity costs for switching from old to new ICT technology may enable developing countries to learn from the experiences of advanced economies from the outset and adopt more efficiently technologies through leapfrogging (Piatkowski 2002 and Wong 2002). An example is the penetration of cellular phones, which has surpassed fixed lines in a number of developing countries (see Figure 4).

However, despite the potential advantages of being a late-comer, some ICTs are not amenable to leapfrogging but require instead a stock of existing ICT capital. The internet, for instance, cannot be utilized without a computer and data communication access. Also, there are likely network effects in the application of ICT at least in some areas, which may create an effective barrier to widespread ICT leapfrogging below a certain threshold level. The requirements for technology adoption in terms of human capital also vary across the new technologies, which allows relatively easy leapfrogging in some areas, such as mobile telephony, while other technologies, such as effective use of certain software applications, require higher levels of human capital.

\section{Skilled vs. Unskilled Workers}

Evidence from several countries suggests that the ICT revolution is skill-biased and increases demand for high-skilled relative to low-skilled workers creating a significant disparity in wages.

20. Social saving is defined as the accumulated welfare benefits of the decline in prices of ICT goods, i.e. a generalization of consumer surplus used to describe the welfare benefits achieved for past technological innovations. Consumer surplus is calculated in this case for the year 1999 from the fall in prices between 1992 and 1999. 


\section{Figure 4: Cellular Phone Explosion in Sub-Saharan Africa}

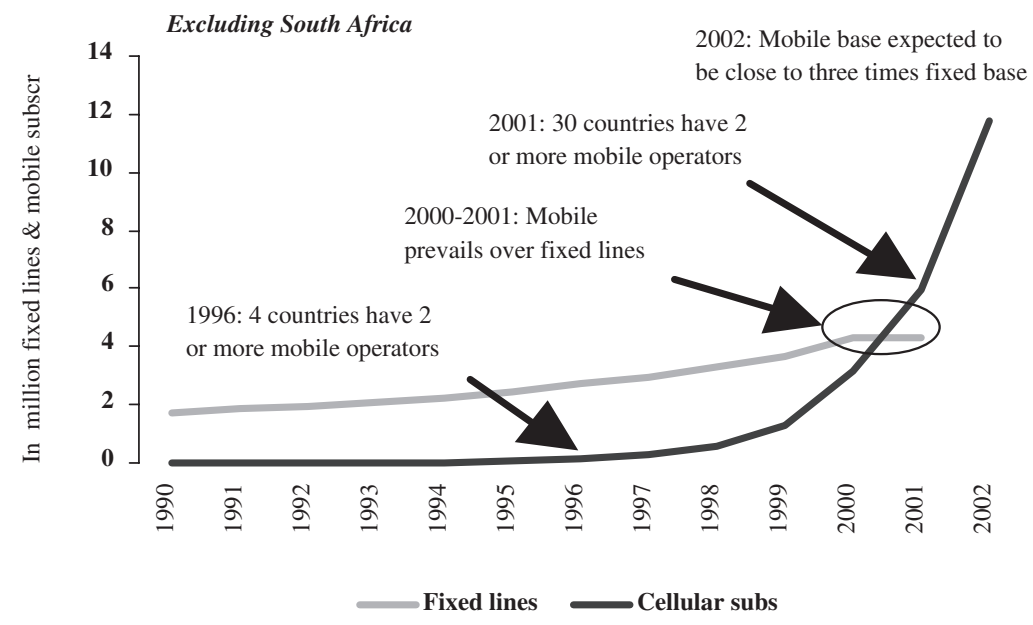

Source: Based on ITU and World Bank data. 2002 data is based on www.EMC-database.com estimates.

Higher-skilled workers are more likely to be hired ${ }^{21}$ than low-skilled workers and that skews the pay differential between educated and less-educated colleagues. For example, in northern Ghana, locals trained in computer skills and management can earn $\$ 6,000$ per year while the average gross national product (GNP) per capita in Ghana is $\$ 390$ (Kenny 2003).

In developing countries, the majority of ICT users are from the most educated sector of the population. This means they reap the benefits and economic opportunities while the uneducated are excluded. In Ethiopia, for instance, 98 percent of internet users had a university degree in 1998 (CABECA 1998). However, the skills required for using ICT are gradually diminishing, as more people become familiar with them. For instance, in the service sector, using computers often involves simple, repetitive tasks that are easy to learn. Over the long-term, as some ICT applications become more user-friendly, it is likely to increase the value of less-skilled workers and reduce the skill bias (IMF 2001).

21. Jorgenson (2001) points out that high-skilled workers are likely complementary to ICT, while low-skilled workers are substitutable. 

Chapter 4

\section{FACTORS INFLUENCING THE CONTRIBUTION OF ICT TO ECONOMIC GROWTH}

S

ome countries, population groups, and certain industries evidently have so far benefited more than others from the ICT revolution. What are the reasons behind this? What are the factors that account for variations in ICT's contribution to economic growth?

It is not surprising that the same countries that lag in ICT adoption also lag generally in economic development. The factors that promote overall economic development are the same factors that enable a country, a population group or an industry to successfully harness ICT's benefits.

ICT capital deepening, as noted earlier, has been a driving force for economic growth. In comparison to developed countries, developing countries are financially constrained and therefore, ICT investment is relatively limited. ICT spending in developing countries rose twice as fast as the OECD average (see Figure 5). However, developing countries continue to lag significantly behind developed countries in terms of ICT expenditure as a percentage of GDP. In 2002, this ratio was about 10 percent in the ten countries with the highest ICT expenditure-to-GDP ratio, ${ }^{22}$ 8 percent among the four Asian NIEs, and only 3.8 percent in India and Russia (World Economic Forum 2003).

In absolute terms, the disparity between developing and developed countries is far worse. On average, the United States spends $\$ 3,500$ per person per year on ICT. In comparison, China spends $\$ 50$ and Bangladesh only spends \$1 per person on ICT (Pitt and Qiang 2003). Piatkowski (2002) suggests that relatively small ICT investments are one reason for the apparent lack of economic benefits from ICT diffusion experienced in the transition economies of Central Asia.

Moreover, countries vary in their ability to achieve low ICT investment costs and high returns. The growth of TFP accelerated more in higher- income countries, which suggests that they are better equipped to realize the gains that come from using ICT.

22. These "top ten" countries are Australia, Colombia, Czech Republic, Denmark, Netherlands, New Zealand, Singapore, Sweden, Switzerland, and United Kingdom. 


\section{Figure 5: Ten Countries With the Highest Growth Rate of ICT SPENDING, | 993-200|}

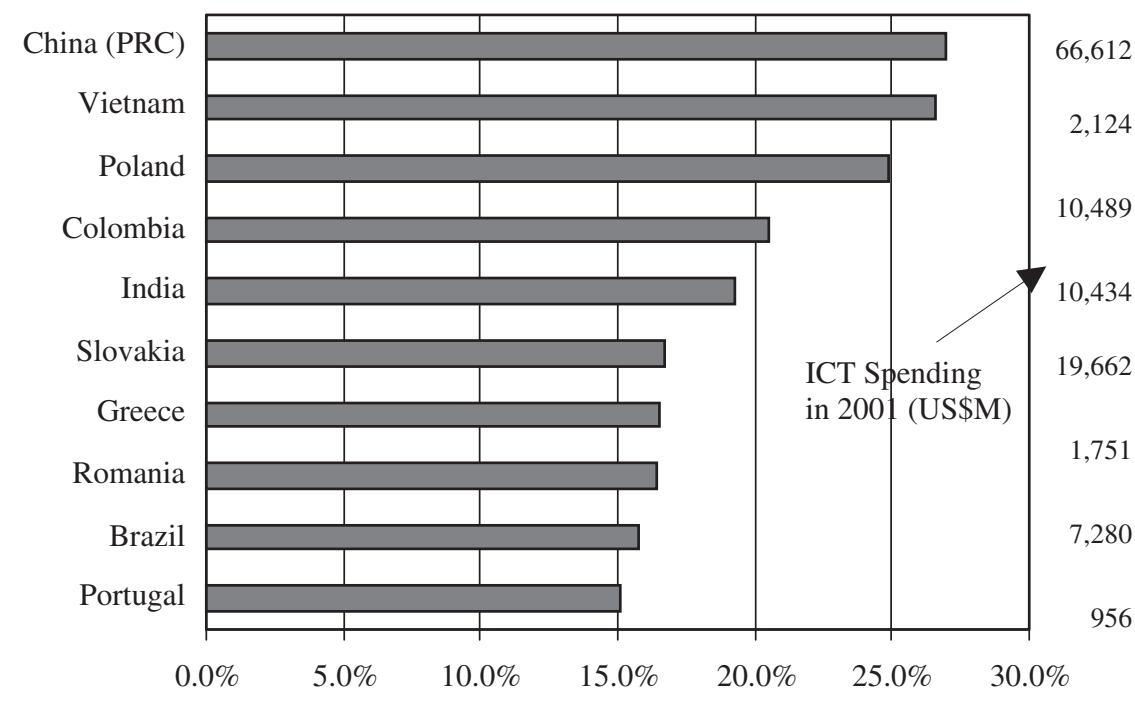

Data Source: WITSA (2002).

Investment, however low, that generates limited returns in developing countries could be due to three factors:

1. There may be both high investment and operational costs due to a lack of adequate institutions, including the ICT regulatory framework and legal environment;

2. Human capital may be low, making it harder to adopt, understand and apply ICT;

3. There may be a threshold level associated with network effects that prevents high returns before a critical mass of ICT investment and usage is reached.

\section{High Investment and Operation Costs}

Production of some ICT services and efficient ICT use rely heavily on a dependable infrastructural framework. However, most developing countries do not possess an adequate information and communications infrastructure (see Table 5 ) and consequently, service is limited and expensive. Promoting competition in the telecommunications sector can cause ICT prices to drop and usage to increase. Regulatory reform in the telecommunications sector can play an important role in promoting competition and in encouraging ICT investment.

However, an adequate communication infrastructure is only part of the challenge. The high costs associated with building a network, as well as the market structure and the regulatory framework in its operation must also be taken into account. Each factor alone could make access to a reliable communication infrastructure expensive for ICT end users. High costs inevitably will limit ICT use and expansion. Many observers identify high user cost as a major impediment to the diffusion of internet services in developing countries. Onyeiwu (2002) maintains that, given extremely low levels of per capita income in African countries, the prices of connectivity, hardware, and of software are so prohibitive that only affluent urban dwellers can afford to pay for internet access.

Aside from the regulatory and market structure in the telecommunications sector, openness to trade, the flexibility of product and labor markets, and the business environment more generally, 


\begin{tabular}{|c|c|c|c|c|c|c|c|c|}
\hline \multirow[b]{2}{*}{ Country Groups } & \multicolumn{2}{|c|}{ Personal Computers } & \multicolumn{2}{|c|}{ Internet Users } & \multicolumn{2}{|c|}{ Telephone Mainlines } & \multicolumn{2}{|c|}{ Mobile Phones } \\
\hline & 1995 & 2001 & 1995 & 2001 & 1990 & 2001 & 1995 & 2001 \\
\hline \multicolumn{9}{|l|}{ Income Breakdown } \\
\hline $\begin{array}{c}\text { High-income OECD } \\
\end{array}$ & 188 & 363 & 34 & 360 & 455 & 574 & 89 & 690 \\
\hline Developing countries & 14 & 34 & 2 & 37 & 52 & 104 & 4 & 94 \\
\hline Least developed & - & 4 & - & 3 & 3 & 7 & 0 & 8 \\
\hline \multicolumn{9}{|l|}{ Regional Breakdown } \\
\hline Northern America & 273 & 623 & 68 & 467 & 555 & 660 & 108 & 382 \\
\hline Western Europe & 174 & 325 & 30 & 345 & 445 & 572 & 84 & 747 \\
\hline East Asia and Pacific & 82 & 158 & 14 & 177 & 148 & 222 & 36 & 278 \\
\hline $\begin{array}{l}\text { Eastern Europe \& } \\
\text { Central Asia }\end{array}$ & 26 & 81 & 5 & 65 & 130 & 232 & 4 & 199 \\
\hline $\begin{array}{l}\text { Middle East and } \\
\text { North Africa }\end{array}$ & 28 & 62 & 1 & 61 & 89 & 147 & 16 & 163 \\
\hline $\begin{array}{l}\text { Latin America and } \\
\text { the Caribbean }\end{array}$ & 17 & 49 & $\mathrm{I}$ & 63 & 66 & 145 & 9 & 142 \\
\hline Sub-Saharan Africa & - & 12 & - & 9 & 9 & 19 & 1 & 30 \\
\hline South Asia & 0 & 4 & 0 & 4 & 5 & 20 & I & 9 \\
\hline
\end{tabular}

Notes: .. = Data not available, $0=$ less than half the unit shown, and the classifications are based on the definitions in the World Bank's Development Indicators Database. All countries with a population below one million are excluded. The group average was calculated when data for at least half the countries was available.

Source: Based on ITU (2002) created by Pohjola, Matti (2003).

are also likely factors behind differences in the uptake and diffusion of new technologies between countries. (OECD 2000, 2001)

\section{Low Human Capital}

The use of ICT depends also on a solid pool of skilled workers. Several studies demonstrate that variations in the rate of returns from ICT production and use between countries are related to levels of human development (Hargittai 1999, Joseph 2002, Rodriguez and Wilson 2000). A welleducated population is far more likely to capitalize on the productivity gains from ICT. Education in general, and the ability to read and speak English in particular, play a critical role in ICT adoption and application. ${ }^{23}$ In 2002, about two-thirds of all web sites were in English. ${ }^{24}$

ICTs, such as the internet were designed with the capital/labor endowments and the economic structure ${ }^{25}$ of developed countries in mind. Therefore, introducing ICTs into developing countries with a lower capital-labor ratio results in relatively high adjustment costs. These costs initially

23. An example of the importance of English in internet usage is Slovenia, where 75 percent of people who considered themselves fluent in English used the internet versus only 1 percent of non-English speakers.

24. http://www.glreach.com/globstats/index.php3

25. Service sub-sectors that are more information-intensive and therefore have a greater potential for ICT use, such as finance and business services, constitute a larger share of the economy in developed countries. Moreover, the service sector has lagged behind manufacturing in productivity growth, so services companies in advanced economies where labor is expensive have strong incentives to substitute ICT for labor in the expectation of increased productivity (Kraemer, Dedrick and Shih 2000). The industrial structure of developing countries-with abundant labor-limits investment opportunities compared to developed countries with high-tech industries. 
adversely effect productivity growth until the new technology is absorbed into the economy (Daveri 2002). This barrier may be formidable enough to deter ICT diffusion even if the long-term benefits outweigh the short-term costs.

Unfortunately, the amount of resources allocated to education and R\&D (see Box 1) in developing countries is insufficient to create the levels of human capital ICT requires. In developing countries, discretionary expenditure for secondary schools is as low as $\$ 12$ per person per year yet the cost to introduce computers in the classroom is estimated to be $\$ 100$ per student (Kenny 2003). Reform in this area, while benefiting economic development in general, is particularly important for the production and use of ICT. However, it is unlikely resources would go to ICT when there is barely enough money for universal primary schooling. Therefore, competing demands on scarce resources need to be carefully assessed.

\section{BOX I: DISPARITY IN R\&D SPENDING}

R\&D is important for understanding and absorbing internationally developed knowledge of ICT, for upgrading domestic R\&D skills, and for enabling active participation in international R\&D networks (Piatkowski 2002). In most developing countries R\&D expenditure is minimal. In transition countries, R\&D expenditure is generally less than one percent of GDP compared to an average of more than two percent in OECD countries (Laafia 2000), and in South Asia 0.8 percent and sub-Saharan Africa only 0.2 percent (World Bank 2000). In absolute terms, R\&D expenditure by the United States alone is three times more than all developing countries combined, and 40 times that of all low-income countries combined.

Source: Pitt and Qiang (2003).

In addition to insufficient educational and R\&D expenditures, developing countries also suffer from the flight of their relatively scarce well-educated, highly-skilled workers to advanced economies. Over the past two decades, only 90,000 of the 260,000 students-or little more than one-third-sponsored by the Chinese government to study abroad returned to China, observed Meng and Li (2001). Brain-drain does result in foreign workers sending home roughly $\$ 75$ billion in remittances per year (Castles 2000), but the loss of expertise and potential entrepreneurs has long-term negative effects on economic growth far greater than the gains from remittances-even if you factor in the wealth of experience returning students bring to their home countries. With the recent liberalization of visa regulations in both North America and Europe for ICT migrants due to increasing demand for skilled ICT workers, the brain drain is likely to continue.

\section{Lack of Network Effects}

The feature of strong network effects in the application of ICT may also partly explain the disparity in investment returns from ICT. Once a critical mass of investments is reached, network externalities-there are increasing benefits per connection to the network the higher the number of other connections-come into effect and marginal returns on ICT investment are increasing, at least up to a point. Therefore, the development of the ICT infrastructure needs to reach a certain threshold before the network effect begins to have an impact on additional ICT investment (Röller and Waverman 2001).

Daveri (2002) provides a related reason for why ICT investment does not always translate to economic growth. He argues that if the initial stock of ICT capital is low-where the investment costs are sunk, such as fixed cost for initial infrastructure building, ICT investment might be simply unproductive on impact and hence generate no additional output upfront. Nevertheless, such investment is indispensable for any subsequent investments to be productive. Piatkowski (2002) notes that the least-developed countries are not likely to invest more than one percent of GDP on ICT. That is arguably too insignificant to make a difference or to generate more ICT capital or to positively affect economic growth. 
Chapter 5

\section{POLICY IMPLICATIONS}

$\mathrm{T}$

The previous sections raise at least two important questions for policymakers. First, what can countries - particularly developing countries - do to create an environment to attract ICT investment and promote ICT use? Second, how can countries maximize returns from ICT investments and have them generate economic growth? The following section ${ }^{26}$ addresses these questions mainly in light of the needs of developing countries. These countries face far more formidable challenges than industrialized countries, but some policy implications pertain to more industrialized countries as well.

\section{Institutional Policies of an Enabling Environment}

ICT is neither a panacea nor the sole impetus for economic growth. It cannot replace the institutional capacity which lays out the foundations for successful economic development. Institutions are, to a certain extent, a precondition for successful ICT development. But ICT, once developed and incorporated into a society, can accelerate the process of change that fosters overall development. The need to attract private investments, the transfer and use of new ICT, and the related reorganization of economic activity, create challenges for legal and regulatory arrangements.

\section{Information and Communications Infrastructure Reform}

Cross-country evidence strongly suggests that well-regulated economies with a competitive climate for cultivating an information infrastructure beget lower costs, better service, wider access (see Figure 6) and greater diffusion of telecommunications and internet services (World Bank 2002, Colecchia and Schreyer 2001). Brazil's telecommunication's deregulation, for instance, resulted in access costs dropping. In 1998, Brazilians paid $\$ 33.20$ for 20 hours of Internet dial-up. Two years

26. An overall policy and institutional environment that favors economic growth and technological innovation are critical for ICT to contribute to growth. But a review of overall growth policy is beyond the scope of this paper. 


\section{Figure 6: Cumulative Annual Growth Rate of Mainline and Mobile Penetration IN DEVELOPING COUNTRIES, 1996-200I}

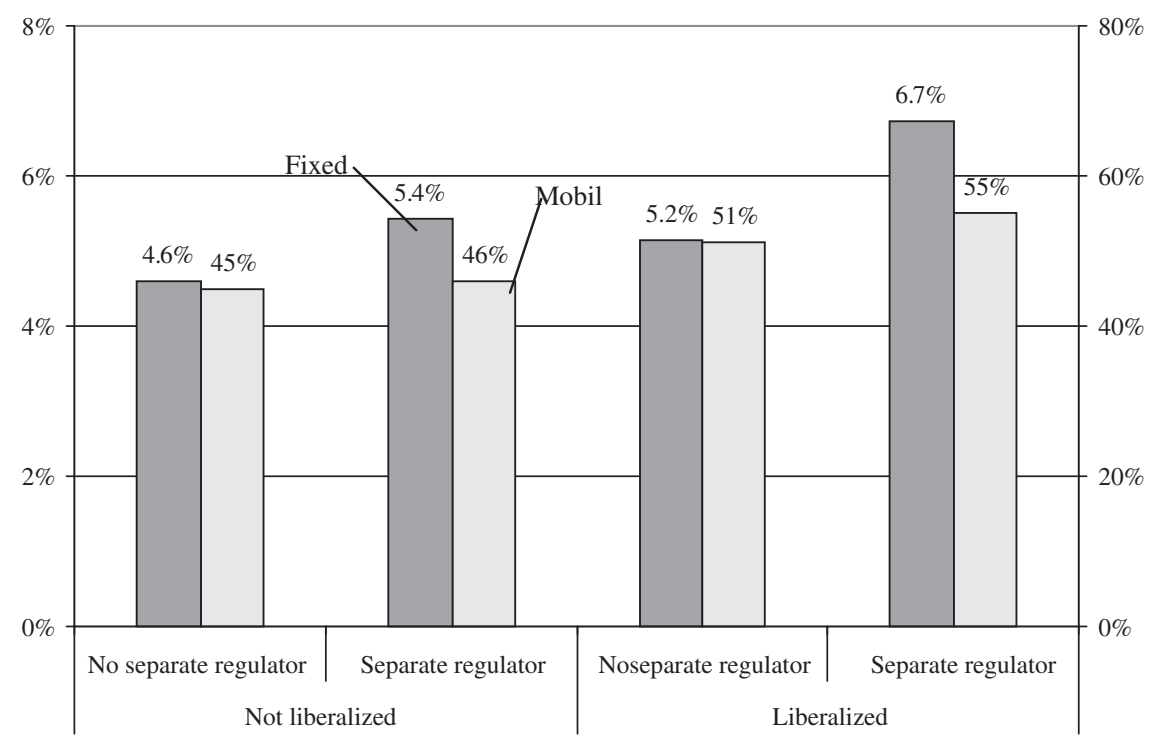

Source: Authors' calculation based on ITU 2002 data.

later, after deregulation, the price dropped to $\$ 14.70$ for 20 hours. (Schneider 2002). Regulatory policies that promote competition are crucial to develop the infrastructure and to foster an environment conducive to higher levels of ICT investment and use, consistent with the demands of an increasingly dynamic global ICT economy. Equally important is access expansion through sector reform and universal access programs. At a minimum, the basic communication tools much reach the threshold level necessary for market forces to function and network effects to take place. For example, the government of Chile took a proactive sectoral approach by establishing the Telecommunications Development Fund in 1994. The fund was financed by the national budget and helped to catalyze additional private investment in payphone service in rural and urban areas with low income and low telephone density. As a result, the number of households with telephones jumped to 75 percent in 2000 from under 20 percent in 1988 (Colecchia and Schreyer 2001).

\section{Trade Openness}

An environment that allows free trade is critical for spreading knowledge and innovations via imports. A liberal trade environment enables international R\&D to spillover and makes leapfrogging possible (Piatkowski 2002). Lower consumer prices and cheaper imports of ICT hardwaresuch as PCs-software and services will promote the spread of ICT technology. Economic openness is identified as the most important factor explaining variations in ICT access within Africa (Onyeiwu 2002). Therefore, countries wishing to encourage ICT use should remove trade barriers, reduce tariffs and relax laws and regulations that hinder the adoption and diffusion of imported technology.

However, Mayer (2002) argues that unilateral trade liberalization in developing countries has not achieved anticipated benefits from technology imports. Trade barriers in developed countries limit their capacity to generate foreign exchange earnings and thus, their ability to import ICT goods and services. Thus, not only do developing countries need to lower their trade barriers but developed countries as well. Developing countries need to fully understand new and existing trade 
issues and the industry dynamics that can create new opportunities. In the World Trade Organization's (WTO) negotiations, developing countries should maximize any leverage they gain from trade offers to cultivate their own ICT development.

\section{Policies to Maximize ICT Returns}

\section{Network/Spillover Effects}

Each country differs in ICT development, infrastructure, and human capacity. Policies should be based on a comprehensive assessment of these factors and targeted to facilitate spillover and network effects. In a regional context, policy coordination opens the possibility spillover and complementation effects.

A domestic ICT production sector, such as manufacturing computers, may act as a catalyst for greater use of ICTs throughout other sectors. The sector can create demand for the products by introducing ICT services into the rest of the economy. While this is not automatic, appropriate policies can capitalize on such spillover effects. Ireland, a major ICT manufacturer and exporter, has leveraged its ICT production activities by offering professional services including outsourcing, network management, custom programming, software localization, call center operations, systems integration, and Web development services. This service sector initially emerged as a by-product of ICT production, but now prospers independently demonstrating the positive spillover effects a domestic ICT production sector can produce.

However, in some countries, the domestic ICT producing sector is simply too small to generate much economic spillover, yet these countries might benefit from spillover effects from their neighbors (Onyeiwu 2002). Take Botswana, Mauritius, and Namibia and as an example. It is quite expensive for them to directly import computer hardware and software because their markets are relatively small. In comparison, their economically more advanced neighbor, South Africa, has invested considerably in ICTs and is a larger market. Importing computer technology from South Africa is cheaper for these countries because transportation costs are quite low. By linking networks, countries can also exploit complementation effects. In East Asia, the economics of the production of ICT goods has generally provided significant regional effects, resulting in the "flying geese" pattern of diffusion of production from the more advanced countries to their less advanced regional neighbors.

\section{"Adaptation Close to Use" to Match Local Needs and Capacity}

Some developing countries simply cannot provide sufficient incentives to encourage ICT production. Nor do they have adequate coffers to spend on R\&D and promoting ICT use in the short-term. Moving toward "adaptation close to use" might be an interim solution. This solution involves adapting ICT applications for local use and to local conditions that can be adjusted by local users reorganizing and updating their businesses and capacity. The type of technologies suitable for this approach in developing countries include those that require less human or physical capital, that match the existing systems, institutional structures and policies (Heeks and Kenny 2003), and that have flexible applications like voice communication, email and the Web (vis-à-vis rigid applications like decision support systems).

For the "adaptation close to use" to work effectively, it is essential to establish policies that encourage alliances among the public sector (to encourage ICT use ${ }^{27}$ ), the private sector (to identify business' needs and desired applications) and R\&D institutions (to find local solutions). Such cooperation can ensure that resources—buildings, people, networks, hardware, software applicationsare available and used efficiently to match local needs and optimize returns on ICT investment.

27. For instance, government policies encouraging e-government applications, enabling small and medium enterprises to use ICT, and sector specific-ICT applications such as telemedicine, e-learning, online tourism may be useful to promote demand. 

$\mathrm{I}$ CT has been widely used to positively affect economic development. Its applications provide access to worldwide information and allow for collaboration between people on different continents. Greater access to information and opportunities for collaboration can create job opportunities, ${ }^{28}$ transfer of skills, and greater efficiency and transparency in politics and business. This paper focuses on the linkage between ICT and output growth and summarizes the findings in the literature on the contributions to labor productivity growth from ICT-related capital deepening and ICT production.

In developing countries, due to resource constraints, ICT's contribution to overall economic growth is limited. Many developing countries face challenges because of their relatively small ICT investment and limited ability to achieve high ICT investment returns.

Yet, opportunities exist to:

Strengthen institutions to create a business climate that attracts investment and promotes use. Exploit network and spillover effects by creating domestic demand.

Promote "adaptation close to use" to match local potential and local needs.

Implementing these policies would contribute to increased investment flows, greater returns on investments and sustainable economic growth. Moreover, ICTs can be used as tools to broaden, enrich and enlighten people and institutions in a way that expedites overall economic development.

28. Governments are sometimes reluctant to foster the development of an ICT industry because of potential concerns of unemployment ('displacement effect'). Large-scale adoption of ICTs may reduce the demand for low-skilled labor. Creation of new ICT jobs may counterbalance potential displacement effects. 



\section{REFERENCES}

Baliamoune, Mina N. 2002. "The New Economy and Developing Countries: Assessing the Role of ICT Diffusion.” August.

Bayoumi, Tamim and Markus Haacker. 2001. "It's Not What You Make, It's How You Use IT." IMF Working Paper.

Basu, Susanto, John G. Fernald, and Matthew D. Shapiro. 2001. "Productivity Growth in the 1990s: Technology, Utilization, or Adjustment.” NBER Working Paper No. 8359.

Beaudry, Paul and David Green. 2001. "Population Growth, Technological Adoption and Economic Outcomes: A Theory of Cross-Country Differences for the Information Era.” NBER Working Paper No. w8149.

Bloom, David E., David Canning, and Jaypee Sevilla. 2002. "Technological Diffusion, Conditional Convergence, and Economic Growth", NBER Working Paper No. w8713.

CABECA. 1998. "Connectivity in Africa: Use, Benefits and Constraints of Electronic Communication-Synthesis Report, Part 2: Overview of the Findings of the Project" Addis Ababa: UNECA/PADIS.

Castles, S. 2000. "The Impacts of Emigration on Countries of Origin." In Yusuf, S. Evenett and W. Wu, eds., Local Dynamics in an Era of Globalization. New York: Oxford University Press.

Cogburn, Derrick L. and Catherine Nyaki Adeya. 2001. "Prospects for the Digital Economy in South Africa-Technology, Policy, People and Strategies.” WIDER Discussion Paper No. $2001 / 77$.

Colecchia, Alessandra and Paul Schreyer. 2001. "ICT Investment and Economic Growth in the 1990s: Is the United States a Unique Case? A Comparative Study of Nine OECD Countries." OECD Working Paper No. DSTI/DOC(2001)7.

Dasgupta, S., S. Lall, and D. Wheeler. 2001. "Policy Reform, Economic Growth, and the Digital Divide: An Econometric Analysis," World Bank Development Research Group Working No. 2567.

Daveri, Francesco. 2003. "Information Technology and Productivity Growth Across Countries and Sectors." IGIER Working Paper No. 227. 
Daveri, Francesco. 2002. “The New Economy in Europe, 1992-2001.” WIDER Discussion Paper No. 2002/70.

Dedrick, Jason, Vijay Gurbaxani, and Kenneth L. Kraemer. 2002. "Information Technology and Economic Performance: Firm and Country Evidence." Center for Research on IT and Organizations, University of California, Irvine.

Dedrick, Jason, Vijay Gurbaxani, and Kenneth L. Kraemer. 2001. "Information Technology and Productivity Growth at the Firm and Country Level." Center for Research on IT and Organizations, University of California, Irvine.

De Gregorio, José and Jong-Wha Lee. 2000. “Economic Growth in Latin America: Sources and Prospects." Global Development Network.

The Economist. 2001. "The digital revolution is helping the poor, too." November 10, 2001.

Evangelista, Benny. "Virus Pushes Schools to Go Virtual." San Francisco Chronicle, April 21, 2003.

Gordon, Robert J. 2003. "Hi-tech Innovation and Productivity Growth: Does Supply Create Its Own Demand?” NBER Working Paper No. w9437.

Gordon, Robert J. 2002. "Technology and economic Performance in the American Economy," NBER Working Paper No. 8771.

Haacker, Markus and James Morsink. 2002. "You Say You Want A Revolution: IT and Growth." IMF Working Paper.

Hargittai, E. 1999. “Weaving the Western Web: Explaining Differences in Internet Connectivity Among OECD Countries." Telecommunications Policy, 23 (10-11): 701-18.

Hamilton, Paul. 2000. "Global: In Focus 2001: World Telecoms." Communications Week International, October 23, 2000.

Heeks, Richard and C. Kenny. 2003. "ICTs and Development: Convergence or Divergence for Developing Countries?" Mimeo. World Bank.

Hsieh, Chang-Tai. 2002. "What Explains the Industrial Revolution in East Asia? Evidence from the Factor Markets." American Economic Review.

IMF. 2001. "The Information Technology Revolution.” In the World Economic Outlook. October. Washington, DC: IMF.

Idris, Kamil. “Intellectual Property—A Power Tool for Economic Growth.” World Intellectual Property Organization (WIPO).

Inzerillo, Ugo. 2002. "Productivity in Europe and the United States: Analysis of the Determinants and Role of the New Economy." Center for European Integration Studies.

ITU. 2002. World Telecom Indicators. Geneva.

Japan Economic Planning Agency. 2000. Keizai Hakusho (Economic Survey of Japan). Tokyo.

Jensen, Mike. 2003. “African Regional: The African Internet-A Status Report.” World Markets Telecoms in Africa.

Jorgenson, Dale W. 2002. "Information Technology, Education, and the Sources of Economic Growth across U.S. Industries." U.S. Congressional Budget Office.

Jorgenson, Dale W. 2001. "Information Technology and the U.S. Economy." American Economic Review, 91(1) March: 1-32.

Jorgenson, Dale W. and Kevin J. Stiroh. 2000. "Raising the Speed Limit: US Economic Growth in the Information Age." Brookings Papers on Economic Activity: 1, Brookings Institution, pp. 161-67.

Joseph, K. J. 2002. "Growth of ICT and ICT for Development: Realities of the Myths of the Indian Experience.” WIDER Discussion Paper No. 2002/78.

Kenny, Charles. 2003. "The Internet and Economic Growth in LDCs: A Case of Managing Expectations?" Oxford Development Studies 31(1).

Kraemer, Kennetch L., Jason Dedrick, and Eric Shih. 2000. "Determinants of IT Investment at the Country Level." Center for Research on IT and Organizations and University of California at Irvine. 
Kraemer, Kenneth L. and Paul Tallon. 1999. "The Information Technology and Economic Development: Ireland's Coming of Age with Lessons for Developing Countries." Center for Research on IT and Organizations, University of California, Irvine.

Krugman, Paul. 1979. “A Model of Innovation, Technology Transfer and the World Distribution of Income." Journal of Political Economy 87(2).

Kun, M. 2002. "Information Will Deliver Social Value in Latin America." Gartner Research, September 5, 2002.

Kun, M. 2002. "The Public and Private Sectors Bridge-Chile's Digital Divide." Gartner Research, September 6, 2002.

Laafia, I. 2000. "R\&D Expenditure and Personnel in Candidate Countries and the Russian Federation in 1998." Eurostat. Statistics in Focus, Theme 9-3/2000.

Lanvin, B., Christine Z. Qiang, Pamela Mar, and F. Richter. 2003. "Impacts of China's WTO Accession on its ICT Competitiveness.” In Global IT Report 2002/3. Geneva: Global Economic Forum.

Lee, Frank C. and Dirk Pilat. 2001. "Productivity Growth in ICT-Producing and ICT-Using Industries-A Source of Growth Differentials in the OECD?" OECD Working Paper No. DSTI/DOC(2001)4.

Lee, Il Houng and Yougesh Khatri. 2003. "Information Technology and Productivity Growth in Asia." IMF Working Paper.

Lee, Youngsoo Lee, Jeonghun Oh, and Hwanjoo Seo. 2002. "Digital Divide and Growth Gap: A Cumulative Relationship.” WIDER Discussion Paper No. 2002/88.

Mattoo, Aaditya, Randeep Rathindran, and Arvind Subramanian. 2001. "Measuring Services Trade Liberalization and Its Impact on Economic Growth: An Illustration.” Mimeo. World Bank/IMF Working Paper.

Mayer, Jörg. 2002. “Technology Diffusion, Human Capital and Economic Growth in Developing Countries." UNCTAD Discussion Paper No. 154.

Meng, Qingxuan and Mingzhi Li. 2001. "New Economy and ICT Development in China.” WIDER Discussion Paper No. 2001/76.

OECD. 2002a. Measuring the Information Economy. Paris.

OECD. 2002b. "Human Capital, Technology and Sectoral Policies for Growth." In Economic Surveys: Japan. Paris.

OECD. 2001. "Computer Price Indices and International Growth and Productivity Comparisons." OECD Working Paper No. STD/DOC(2001)1. Paris.

OECD. 2000. A New Economy? The Changing Role of Innovation and Information Technology in Growth. Paris.

Oliner, Stephen D. and Daniel E. Sichel. 2000. "The Resurgence of Growth in the Late 1990s: Is Information Technology the Story?" Journal of Economic Perspectives 14 (Fall): 3-22.

O.M. Nour, Samia Satti. 2002. "The Impact of ICT on Economic Development in the Arab World: A Comparative Study of Egypt and the Gulf Countries.” INTECH. September 2002.

Onyeiwu, Steve. 2002. "Inter-Country Variations in Digital Technology in Africa: Evidence, Determinants and Policy Implications.” WIDER Discussion Paper No. 2002/72.

Piatkowski, Marcin. 2002. "The 'New Economy' and Economic Growth in Transition Economies.” WIDER Discussion Paper No. 2002/62.

Pilat, Dirk. 2003. "ICT and Economic Growth-Evidence from OECD Countries, Industries and Firms." Directorate for Science, Technology and Industry, OECD, DSTI/IND/ICCP(2003).

Pitt, Alexander and Christine Z. Qiang. 2003. "ICT and Economic Growth: A Developing Country Perspective." Mimeo. IMF.

Pohjola, Matti. 2003. "The Adoption and Diffusion of ICT Across Countries: Patterns and Determinants." To be published in The New Economy Handbook. Academic Press.

Pohjola, Matti. 2001. "Information Technology, Productivity, and Economic Growth.” Oxford: Oxford University Press. 
Pohjola, Matti. 2000. "Information Technology and Economic Growth: A Cross-Country Analysis." WIDER Working Paper No. 173.

Robyn, Ghislain. 2001. "Measuring the Economic Importance of ICT.” Discussion Paper No. 2, UNIDO.

Rodriguez, F. and E. Wilson. 2000. "Are Poor Countries Losing the Information Revolution?” infoDev. World Bank.

Röller, L.-H. and L. Waverman. 2001. "Telecommunications Infrastructure and Economic Development: A Simultaneous Approach." American Economic Review 91(4): 909-923.

Schreyer, Paul. 2000. "The Contribution of ICT to Output Growth: A Study of the G7 Countries." OECD Working Paper No. 89070.

Schneider, P. H. 2002. "Recent Developments in Information and Communication Technologies and Their Impact on the Brazilian Economy." Paper presented at the Eastern Economic Association Conference, March. Boston.

Senhadji, Abdelhak. 2000. "Sources of Economic Growth: An Extensive Growth Accounting Exercise.” IMF Working Paper No. v. 47, No. 1.

Singh, Nirvikar. 2003. "India's Information Technology Sector: What Contribution to Broader Economic Development?” OECD Development Centre, Technical Paper No. 207.

US BEA. 2002. United States Department of Commerce, Bureau of Economic Analysis.

United States Council of Economic Advisers (US CEA). 2001. Economic Report of the President. Washington: Government Printing Office.

Urban, Dieter M. 2000. "Neoclassical Growth, Manufacturing Agglomeration and Terms of Trade," Ld.A Working Paper No. 136.

Van Ark, Bart, Johanna Melka, Nanno Mulder, Marcel Timmer, and Gerard Ypma. 2003. "ICT Investment and Growth Accounts for the European Union, 1980-2000." Groningen Growth and Development Centre.

Van Ark, Bart. 2002. "Understanding productivity and income gaps in the OECD area: are ICT and intangibles the missing links?" Groningen Growth and Development Centre.

Van Ark, Bart. 2001. "The renewal of the old economy: Europe in an internationally comparative perspective." University of Groningen and The Conference Board.

World Information Technology and Services Alliance (WITSA). 2002. Arlington, VA, USA.

Wong, Poh-Kam. 2001. "ICT Production and Diffusion in Asia-Digital Dividends or Digital Divide?” WIDER Discussion Paper No. 2001/8.

Wong, Poh-Kam and Annette Singh. 2002. "Preparing for the Digital Economy: ICT Manpower Development in Singapore." Centre for Entrepreneurship National University of Singapore.

World Bank 2000. Global Economic Prospects. Washington, DC.

World Bank 2002. "Information and Communications Technologies in East Asia's Future Growth." Mimeo.

World Economic Forum. 2003. “Global IT Report 2002-2003.” Edited by Soumitra Dutta of INSEAD, Bruno Lanvin of infoDev (World Bank) and Fiona Pauainsead of the World Economic Forum. Oxford University Press. 
Contribution of Information and Communication Technologies to Growth is part of the World Bank Working Paper series. These papers are published to communicate the results of the Bank's ongoing research and to stimulate public discussion.

The worldwide development of information and communication technology (ICT) has accelerated dramatically over the past decade. Technological advances and increased competition have led to falling prices for ICT goods and services, and that has provided a strong incentive to replace other forms of capital and labor with information technology equipment. Increased ICT production and use has the potential to create job opportunities, transfer of skills, and greater efficiency and transparency in politics and business, and thereby contributes to economic growth.

This paper focuses on the linkage between ICT and output growth. It summarizes the findings in the literature on the contribution of ICT to economic growth arising from capital deepening and increases in total factor productivity. The paper contains: (i) the methodologies used to evaluate the different ways that ICT influences productivity growth; (ii) a critical assessment of the magnitude of ICT's contribution to growth in various countries; (iii) a summary of the key factors that increase or obstruct ICT expansion; and (iv) an outline of the challenges that developing countries face in maximizing ICT's contribution to growth-with policy recommendations aimed at surmounting these challenges.

World Bank Working Papers are available individually or by subscription, both in print and online.

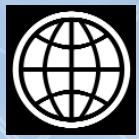

THE WORLD BANK

1818 H Street, NW

Washington, DC 20433 USA

Telephone: 202 473-1000

Internet: www.worldbank.org

E-mail: feedback@worldbank.org

ISBN 0-8213-5722-0

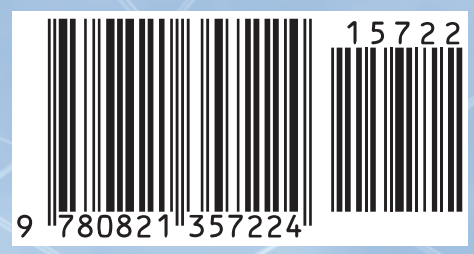

